\section{Non-Reflecting Windows}

Is connexion with the note under this title in NATURE of January 13, p. 59, a correspondent points out that the principle can be applied to the glazing of pictures and of museum cases, both of which applications were explained and discussed, with illustrations, in the Museums Journal of November 1932 (pp. 305-308).

\section{The Zoological Station. Naples}

THE attention of British zoologists, botanists and physiologists is directed to the facilities for research available in the Zoological Station, Naples. A Committee of Section D (Zoology) of the British Association is empowered to nominate competent research workers to a table in the Naples Station which has been maintained by the British Association since 1876. Workers so nominated are provided, without charge, with material and ordinary chemicals and apparatus. The Station possesses a considerable range of apparatus for physiological and biochemical investigations. Applications for the use of the table should be sent to the Chairman and Secretary of the Committee, Prof. J. H. Ashworth, Department of Zoology, The University, Edinburgh, and should specify the nature of the research proposed and the period for which the table is desired.

\section{Geological Society Awards}

THE following awards of the Geological Society of London have been made for this year : The Wollaston medal to Sir Henry Miers, honorary professor of crystallography in the University of Manchester, for his researches on the mineral structure of the earth, and especially in the realms of crystallography and mineralogy; the Murchison medal to Prof. George Hickling, professor of geology in Armstrong College, Newcastle-on-Tyne, for his contributions to geological science in many branches, but especially in the stratigraphy of the Coal Measures and the structure of coal ; a Lyell medal to Dr. Finlay Lorimer Kitchin, of H.M. Geological Survey, in recognition of the value of his contributions to palæontological science; another Lyell medal to Prof. Walter Howchin, emeritus professor of geology and palæontology in the University of Adelaide, South Australia, for his geological and palæontological researches in Australia and particularly for his investigations of ancient glacial deposits; Wollaston fund to Dr. William Richard Jones, of the Royal School of Mines, in recognition of the value of his work in economic geology and his recent investigations in silicosis; Murchison fund to Dr. Wilfrid Jackson, assistant keeper in the Manchester Museum, for his contributions to Pleistocene geology and palæontology and to malacology ; Lyell fund to Mr. Frederick William Shotton, in recognition of the value of his work on the Upper Palæozoic and Quaternary rocks of the Midlands.

\section{Announcements}

DR. W. CAwood has been appointed to a Moseley research studentship of the Royal Society, for work on the accurate determination of molecular weights of gases.
UPON the retirement from the public service of Dame Janet Campbell, as from December 31 and of Sir George Buchanan, as from February 18, Dr. Jane H. Turnbull will be in charge of the Maternity and Child Welfare Division of the Medical Staff of the Ministry of Health and Dr. J. M. Hamill will act as senior medical officer in charge of the Foods Division of the Ministry.

AT the annual general meeting of the British Ecological Society held at Cambridge on January 2-4, the following officers were elected: President, Prof. J. R. Matthews; Vice-President, C. Oldham; Hon. Editor of the Journal of Ecology, Prof. A. G. Tansley ; Hon. Editor of the Journal of Animal Ecology, C. S. Elton; Hon. Secretary, Dr. H. Godwin. The Council unanimously approved the nomination of Prof. H. C. Cowles and Prof. L. Cockayne for honorary life membership of the Society.

THE twentieth International Congress on Alcoholism will be held at the Imperial Institute, South Kensington on July 30-August 3 under the presidency of Lord Astor. The aim of the Congress is to secure a comprehensive world picture of the present position concerning alcoholism in its various ramifications in social life. The mornings will be devoted to the consideration of national surveys, and the afternoons to papers on education, the influence of legislation on the consumption of alcoholic beverages, alcohol in the treatment of disease, the causes and treatment of inebriety, alcohol and eugenics, alcohol and heredity and the organisation of press work. All communications concerning the Congress should be made to the convener, Dr. C. C. Weeks, 33 Bedford Place, W.C.2.

Applications are invited for the following appointments, on or before the dates mentioned :- Examiners for the Aeronautical Inspection Directorate of the Air Ministry-The Secretary (S.2), Air Ministry, Adastral House, Kingsway, London, W.C.2 (Jan. 26). A lecturer in pharmaceutical chemistry in the Department of Pharmacy in the Birmingham Central College-The Principal, Central Technical College, Suffolk Street, Birmingham, 1 (Jan. 31). An assistant chemist in the Royal Naval Cordite Factory, Holton Heath, Dorset-The Secretary to the Admiralty (C.E. Branch) (Feb. 3). A chief veterinary inspector for the Leicestershire County Council-The Clerk of the County Council, 10 New Street, Leicester (Feb. 3). A public analysist for the Metropolitan Borough of Fulham-The Town Clerk, Fulham, London, S.W.6 (Feb. 7). A teacher of domestic science at the National Training College of Domestic Subjects, 72, Buckingham Palace Road, London, S.W.1. A veterinary officer for the County Borough of Wallasey-The Town Clerk, Town Hall, Wallasey.

Erratum. In the table on p. 3 of Nature of January 6, the heading of the third column should be "Manual workers per 100 acres" and not "Manual workers per acre". 